\title{
Valuation of the Durability of the \\ Concrete Used in the Precast Great \\ Soviet Panel System
}

Yamila-Concepción Socarrás-Cordoví; Liliana González-Díaz; Eduardo

Álvarez-Deulofeu; Mayra González-Fernández; Estrella RocaFernández; Raúl Torres-Shoembert

Citation: Y.-C. Socarrás-Cordoví, L. González-Díaz, E. ÁlvarezDeulofeu, M. González-Fernández, E. Roca-Fernández, and R. Torres-

Shoembert, "Valuation of the Durability of the Concrete Used in the Precast Great Soviet Panel System," Revista Facultad de Ingeniería, vol. 29 (54), e10486, 2020.

https://doi.org/10.19053/01211129.v29.n54.2020.10486

Received: December 30, 2019; Accepted: May 24, 2020;

Published: June 18, 2020

Copyright: This is an open access article distributed under license $\underline{\mathrm{CC}}$

BY

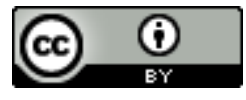

Conflict of interest: The authors state there is no conflict of interest. 


\title{
Valuation of the Durability of the Concrete Used in the Precast Great Soviet Panel System
}

\author{
Yamila-Concepción Socarrás-Cordoví \\ Liliana González-Díaz ${ }^{2}$ \\ Eduardo Álvarez-Deulofeu ${ }^{3}$ \\ Mayra González Fernández ${ }^{4}$ \\ Estrella Roca-Fernández ${ }^{5}$ \\ Raúl Torres-Shoembert ${ }^{6}$
}

\begin{abstract}
The durability of the concrete of the precast Great Soviet Panel system is valued through the resistance to compression, ultrasonic pulse velocity, surface methods, humidity and potential of corrosion. The evaluation is approached, essentially, through experimental and statistical methods, nevertheless, historical-logical and technical methods, such as surveys and interviews, are used in order to gather a bigger amount of information on the resistance to compression of the elements in the original project. While analyzing the results, we can conclude that, in elements in a good technical-constructive state that conform the constructions in exploitation, concrete has an average resistance. However, in elements with the presence of pathological damages, the resistance is low due to the fact that elements show chemical deterioration processes caused by water exposure, which generates the formation of soluble paste compounds, loss of mass, and decrease in mechanical resistance, among other alterations. At the same time, carbonation of concrete is
\end{abstract}

\footnotetext{
${ }_{1}^{1}$ M. Sc. Universidad de Oriente (Santiago de Cuba, Cuba). yamila@uo.edu.cu. ORCID: 0000-0002-3198-3543

2 Ph. D. Universidad de Oriente (Santiago de Cuba, Cuba). liliana@uo.edu.cu. ORCID: 0000-0002-5606-982X

${ }^{3}$ Ph. D. Universidad de Oriente (Santiago de Cuba, Cuba). ealvarez@uo.edu.cu.ORCID: 0000-0003-1819-263X

${ }^{4}$ M. Sc. Universidad de Oriente (Santiago de Cuba, Cuba). mayra@uo.edu.cu. ORCID: 0000-0002-4788-3184

${ }^{5}$ M. Sc. Universidad de Oriente (Santiago de Cuba, Cuba). estrella@uo.edu.cu. ORCID: 0000-0003-0372-1922

${ }^{6}$ Universidad de Oriente (Santiago de Cuba, Cuba). ORCID: 0000-0002-4410-4253
} 
triggered, which, in turn, causes the corrosion of the reinforcing steel. This corrosion leads to the cracking of concrete, delamination of steel, decrease of the concretesteel adhesion, and other manifestations that affect the durability of concrete. Therefore, the incidence of the durability of concrete should be valued in the structural seismic behavior of constructions.

Keywords: compression resistance; concrete system; humidity percentage; potential of corrosion; surface methods; ultrasonic pulse velocity.

\section{Valoración de la durabilidad del hormigón prefabricado utilizado en el sistema gran panel soviético}

\section{Resumen}

Se valora la durabilidad del hormigón del sistema prefabricado Gran Panel Soviético, a través de la precisión de la resistencia a compresión, la velocidad del pulso ultrasónico y el índice esclerométrico. Igualmente, se determinan otros parámetros como la humedad y el potencial de corrosión, que también inciden en la durabilidad del hormigón. Se recurre esencialmente a métodos experimentales y estadísticos, no obstante, se emplean métodos como el histórico-lógico y técnicas como las encuestas y entrevistas, para recopilar mayor cantidad de información sobre la resistencia a compresión de los elementos prefabricados en el proyecto original. Al analizar los resultados se concluye que, en los elementos en buen estado técnico-constructivo, que conforman las edificaciones en explotación, el hormigón es de resistencia media al igual que lo prescribe el proyecto original de este sistema prefabricado. Sin embargo, en los elementos con presencia de daños patológicos la resistencia es baja. Debido a que en estos elementos se evidencian procesos de deterioro químico, causado por el ataque del agua, que generan formación de compuestos solubles de la pasta, la pérdida de masa y la disminución de resistencia mecánica entre otras alteraciones. A la par se desencadena la carbonatación del hormigón, que provoca a su vez la corrosión del acero de refuerzo. Esta corrosión conduce al agrietamiento del hormigón, delaminación del acero, disminución de la adherencia hormigón-acero y demás manifestaciones, que afectan la durabilidad 
del hormigón. Por lo tanto, se debe valorar la incidencia de la durabilidad del hormigón, en el comportamiento sismorresistente de estas edificaciones.

Palabras clave: índice esclerométrico; porcentaje de humedad; potencial de corrosión; resistencia a compresión; sistema prefabricado; velocidad del pulso ultrasónico.

\section{Valoração da durabilidade do concreto pré-fabricado utilizado no sistema grande painel soviético}

\section{Resumo}

Valora-se a durabilidade do concreto do sistema pré-fabricado Grande Painel Soviético, através da precisão da resistência à compressão, à velocidade do pulso ultrassônico e ao índice esclerométrico. Igualmente, determinam-se outros parâmetros como a humidade e o potencial de corrosão, que também incidem na durabilidade do concreto. Recorre-se essencialmente a métodos experimentais e estatísticos, mesmo assim, empregam-se métodos como o histórico-lógico e técnicas como as enquetes e entrevistas, para recopilar maior quantidade de informação sobre a resistência à compressão dos elementos pré-fabricados no projeto original. Ao analisar os resultados conclui-se que, nos elementos em bom estado técnico-construtivo, que conformam as edificações em exploração, o concreto é de resistência média ao igual que o prescreve o projeto original deste sistema pré-fabricado. Porém, nos elementos com presença de danos patológicos, a resistência é baixa. Devido a que nestes elementos evidenciam-se processos de deterioro químico, causado pelo ataque de água, que geram formação de compostos solúveis da pasta, a perda de massa e a diminuição de resistência mecânica, entre outras alterações. Juntamente, desencadeia-se a carbonatação do concreto, que provoca por sua vez, a corrosão do aço de reforço. Esta corrosão conduz à fissuração do concreto, delaminação do aço, diminuição da aderência concreto-aço e demais manifestações, que afetam a durabilidade do concreto. Portanto, deve-se valorar a incidência da durabilidade do concreto, no comportamento sismorresistente destas edificações. 
Palavras chave: índice esclerométrico; porcentagem de humidade; potencial de corrosão; resistência a compressão; sistema pré-fabricado; velocidade do pulso ultrassônico. 
Yamila-Concepción Socarrás-Cordoví; Liliana González-Díaz; Eduardo Álvarez-Deulofeu; Mayra GonzálezFernández; Estrella Roca-Fernández; Raúl Torres-Shoembert

\section{INTRODUCTION}

The Giprostroy Institute in the former Soviet Union created the I-464 series of buildings in the late 1950s. In reality, this was the Soviet adaptation of the French Camus system, patented in 1949 to industrially precast large-format concrete panels. Its use became massive, not only in many former Soviet republics, but in other countries in Europe, as well as in Chile and Cuba.

In Cuba, the implementation of this prefabricated system, under the name of the Great Soviet Panel (GPS), was exclusive in the Santiago de Cuba province; also, some buildings were experimentally constructed in Pilón, Granma province. In the Santiago de Cuba province, between 1964 and 1991, 769 GPS buildings were built, 665 of them were concentrated in the municipality of the same name. These buildings are developed vertically, with four to five levels, and they are characterized by being symmetrical in length and elevation. The architectural plan shows a structure with one to six staircases, but contemplates expansion joints at almost every two staircases; that is, every 32 meters long. Also, there are buildings with and without a balcony, as shown in Figure 1.

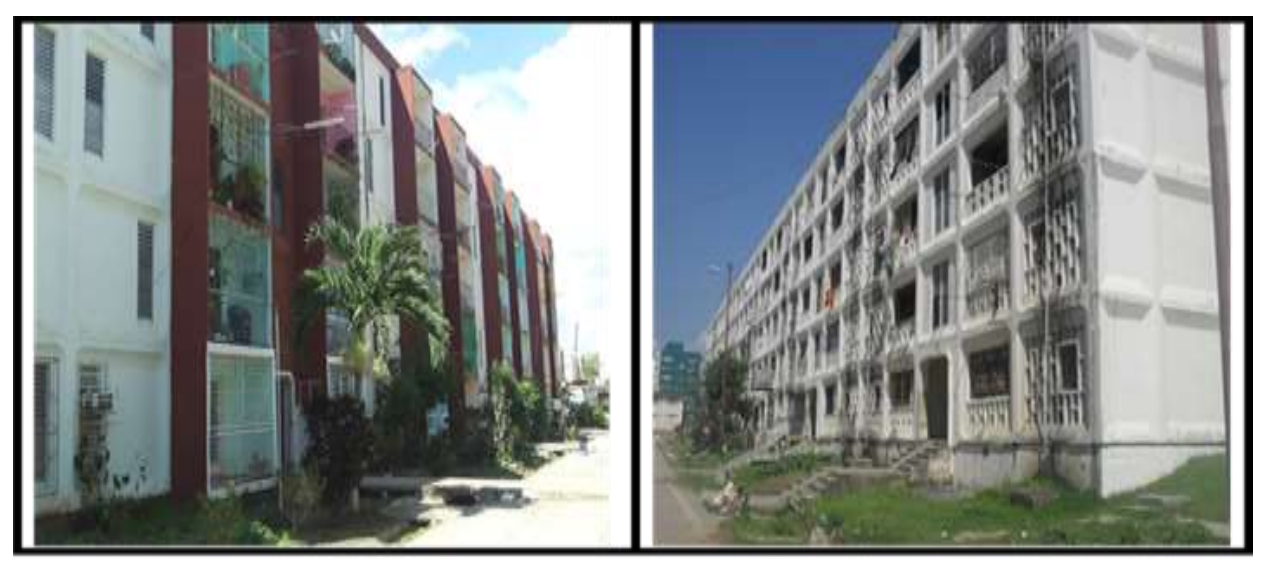

Fig. 1. Buildings built with GPS, with balcony (left), without balcony (right).

All the structural elements of the GPS system are industrially precast. In the catalog, the exterior panels are designated by the letter $E$ and the interiors by letters I, S, and $T$. The letter $P$ is used to designate the precast slabs.

The precast GPS system, due to its structural conception and joint types between its structural elements, has shown adequate behavior in the face of earthquakes of 
great intensity, which have occurred in Chile (1985, 2010 and 2012), as well as in Armenia (former Soviet Republic) in 1988. However, the community of specialists in the province of Santiago de Cuba has shown concern for these buildings for some time now, due to the pathological damage present in structural elements and joints, as well as to the changes suffered in weight and stiffness.

Díaz [1] carried out one of the first related investigations, where he identified the presence of chloride, sulfate and carbonation ions in the panels of a kitchen, bathroom and living room, as well as in the mezzanine and in covering slabs. The conclusion is that these buildings show a high deterioration. Other researchers such as Morejón et al. [2] focused their objective on evaluating the seismic vulnerability of buildings, stating that they resist a high-intensity earthquake. However, in their analysis, they did not consider the increases in weight and the changes in stiffness present in these buildings, both due to the placement of water tanks, the addition of masonry walls, filling of the lattices, opening or removal of panels and slabs, among others.

With the intention of carrying out more in-depth studies, the present research focuses on evaluating the durability of the concrete used in the prefabricated Great Soviet Panel system, to later on see its possible impact on the seismic-resistant behavior of buildings made with said system. Compressive strength, ultrasonic pulse rate and sclerometric index will be specified, as well as other parameters such as humidity and corrosion potential, which affect the durability of the concrete. Essentially, experimental and statistical methods are used, however, historicallogical methods and techniques, such as surveys and interviews, are used to collect more information on the compressive strength of structural elements in the original project.

\section{Materials AND Methods}

An experimental program was carried out to determine the quality and properties of the concrete of the precast GPS system, under the current exploitation conditions and the ones in the original project. Destructive and non-destructive tests are carried out on precast elements located in the warehouse area of the "Gran Panel Santiago" 
Precast Plant. Non-destructive tests are also applied on precast elements that conform buildings in use. The number of elements to be tested and the necessary controls were defined in correspondence with regulations [3-5]. The equipment, standards and evaluation criteria that were considered in each of the tests carried out are detailed below.

\section{A. Destructive Test to Determine the Compressive Strength According to the Conditions of the Original Project}

For the determination of the compressive strength of the concrete, cores were extracted from 7 precast elements of the Great Soviet Panel system, which still exists in the warehouse area of the "Gran Panel Santiago" Precast Plant. All elements have production date July 18, 1991 and were classified as compliant at the time of production. To extract the cores ( 3 cores per element, for a total of 21), the HILTI 00-130 equipment was used with a $4.5 \mathrm{~cm}$ diameter cutting auger; the requirements of the regulations were considered [ 6].

The compressive strength test was performed according to the standard [7]. The specimens were not submerged in water, since the concrete has been in production for more than 30 years.

\section{B. Non-destructive Tests with Ultrasound and Sclerometer}

These tests were carried out to confirm:

- Compressive strength according to the conditions of the original project

- Compressive strength under current operating conditions with elements in good condition

- Compressive strength under current operating conditions with elements with presence of pathological damage

The same elements from which control samples were taken, elements found in the precast plant, as well as elements that conform buildings in operation (Building $\mathrm{E}$ 16; E-18 and Building U-142; U-143) were tested. In total, the test included 22 elements with the presence of pathological damage with severe involvement levels, as well as 11 in good technical-constructive condition. 
To measure the speed of the ultrasonic pulse, the steel bars were located first, since the wave propagation speed is twice as high in these as in concrete. Then measurements were made close to the bars, parallel to the propagation direction. A total of four measurements of the ultrasonic pulse were made in each element analyzed with the Pundit Lab equipment. The quality of concrete was classified according to the specifications established in Table 1.

Table 1. Qualitative evaluation of concrete according to the speed of the ultrasonic pulse [8].

\begin{tabular}{|l|c|}
\hline \multicolumn{1}{|c|}{ Pulse Speed (m/s) } & Concrete Condition \\
\hline Over 3660 & Good \\
\hline From 2135 to 3660 & Regular \\
\hline Less than 2135 & Poor \\
\hline
\end{tabular}

For sclerometer, the $\mathrm{N}$-type Schmidt hammer was used, and the test was carried out according to standards [9-10]. A total of 15 impacts were made on each element tested and the qualitative evaluation of concrete was made according to the specifications established in Table 2.

Table 2. Qualitative evaluation of concrete according to the Sclerometric Index [10].

\begin{tabular}{|c|c|}
\hline Sclerometric Index (IE) & Concrete quality \\
\hline Values $>40$ & Good \\
\hline 30 to 40 & Average \\
\hline 20 to 29 & Poor \\
\hline Values $<20$ & Cracks and delamination \\
\hline
\end{tabular}

\section{Non-destructive Tests with Humidimeter and Corrosimeter}

These tests were used to determine the percentage of humidity and the corrosion potential in elements with pathological damage. To evaluate the humidity percentage, 10 elements with the presence of humidity were chosen after a visual inspection, these elements are part of buildings in operation. The measurements on the panels were made at $50 \mathrm{~cm}$ from the floor level (in the center) and at $50 \mathrm{~cm}$ below the slab, in order to also define whether the humidity is rising or falling. In the case of the slabs, a $15 \times 15 \mathrm{~cm}$ grid was made, measurements were done in areas where there were moisture stains. The HMT600 Humidimeter was used. 
The ranges of the percentage of humidity in relation to its incidence on corrosion have been established based on the percentage of relative humidity in Cuba. According to Tejera and Álvarez [11], in order to accelerate corrosion, it is necessary, together with a sufficient supply of oxygen, for the humidity of the element to be at least $50 \%$ of the relative humidity. Considering that the average annual relative humidity in Cuba is $78 \%$, Table 3 establishes the ranges of the percentage of humidity in relation to its incidence on corrosion.

Table 3. Incidence of the percentage of humidity in the corrosion.

\begin{tabular}{|c|c|}
\hline Moisture percentage & Incidence on corrosion \\
\hline Up to $39 \%$ & Minimum \\
\hline Greater than $39 \%$ & Maximum \\
\hline
\end{tabular}

The measurement of the corrosion potential was carried out in elements in which exposed steels were observed; the Canin corrosimeter was used. $15 \times 15 \mathrm{~cm}$ grids were made in the area prepared for carrying out the test, in an aim to cover most of it. At the beginning of the measurements, a ground cable connected to the exposed steel reinforcement was placed, and factors that influence the results such as humidity, temperature, thickness of the concrete cover and the oxygen content in the reinforcement, were considered. Typical orders of magnitudes for evaluating the state of corrosion of the steel surface within concrete are shown as intervals in Table 4.

Table 4. Classification of concrete according to the corrosion potential- Typical magnitudes of the measurements [12].

\begin{tabular}{|l|l|}
\hline Water-saturated concrete without $\mathrm{O}_{2}$ & from -1000 to $-900 \mathrm{mV}$ \\
\hline Chloride-contaminated wet concrete & from -600 to $-400 \mathrm{mV}$ \\
\hline Chloride-free wet concrete & from -200 to $+100 \mathrm{mV}$ \\
\hline Carbonated wet concrete & from -400 to $+100 \mathrm{mV}$ \\
\hline Carbonated dry concrete & from 0 to $+200 \mathrm{mV}$ \\
\hline Non-carbonate dry concrete & from 0 to $+200 \mathrm{mV}$ \\
\hline
\end{tabular}

\section{RESULTS}

Table 5 shows the results of the destructive and non-destructive tests on the elements of the "Gran Panel Santiago" Precast Plant. On the other hand, tables 6 to 
8 show the results of non-destructive tests on the elements that conform buildings in operation. Some of the elements tested were from buildings in operation that are in good condition (11), while others (22) present pathological damage such as humidity, corrosion and/or concrete disintegration mechanisms.

\section{A. Destructive and Non-destructive Tests on Elements of the Precast Plant}

The values of the compressive strength of the series of specimens extracted from the elements are presented below, as well as the measured values of the sclerometric index (IE) and the speed of the ultrasonic pulse $(\mathrm{V})$ in these elements.

Table 5. Results of the tests on the elements of the precast plant.

\begin{tabular}{|c|c|c|c|c|l|}
\hline \multirow{2}{*}{ Elements } & $\mathbf{f}$ 'cs & \multicolumn{2}{|c|}{ Sclerometry } & \multicolumn{2}{c|}{ Ultrasonic pulse speed } \\
\cline { 3 - 6 } & $(\mathbf{M P a})$ & IEs & Concrete quality & Vs (m/s) & Concrete quality \\
\hline E-1 & 19.00 & 33 & Average & 2300 & Regular \\
\hline I-10 & 16.83 & 32 & Average & 2500 & Regular \\
\hline E-9 & 18.33 & 34 & Average & 2800 & Regular \\
\hline E-12 & 7.66 & 20 & Poor & 500 & Poor \\
\hline E-2 & 17.00 & 33 & Average & 2500 & Regular \\
\hline P-7 & 19.43 & 35 & Average & 2900 & Regular \\
\hline P-4 & 21.00 & 38 & Average & 3000 & Regular \\
\hline
\end{tabular}

\section{B. Non-destructive Tests on Elements in Good Condition from Buildings in Operation}

The results detailed in Table 6 correspond to the values obtained from the IE and V, when testing elements in good condition that are part of buildings in operation.

Table 6. Results of sclerometry and the speed of the ultrasonic pulse in elements in good condition.

\begin{tabular}{|l|c|c|c|c|}
\hline \multirow{2}{*}{ Elements } & \multicolumn{3}{|c|}{ Sclerometry } & \multicolumn{2}{c|}{ Ultrasonic pulse speed } \\
\cline { 2 - 5 } & IEs & Concrete quality & Vs (m/s) & Concrete quality \\
\hline I-4 & 34 & Average & 3000 & Regular \\
\hline I-3 & 34 & Average & 3000 & Regular \\
\hline E-12 & 43 & Good & 3200 & Regular \\
\hline I-8 & 34 & Average & 3000 & Regular \\
\hline I-7 & 34 & Average & 3000 & Regular \\
\hline E-1 & 37 & Average & 3000 & Regular \\
\hline I-7 & 34 & Average & 3000 & Regular \\
\hline T-1 & 30 & Average & 3000 & Regular \\
\hline P-4 & 39 & Average & 2800 & Regular \\
\hline P-7 & 39 & Average & 2900 & Regular \\
\hline P-4 & 39 & Average & 2900 & Regular \\
\hline
\end{tabular}




\section{Non-destructive Tests on Elements with Pathological Damage in Buildings in Operation}

Tables 7 to 9 show the values obtained for IE, V, percentage of humidity, and corrosion potential, when 22 elements from buildings in operation with the presence of pathological damage were tested.

Table 7. Results of sclerometry and ultrasonic pulse speed in elements damaged.

\begin{tabular}{|l|c|c|c|c|}
\hline \multirow{2}{*}{ Elements } & \multicolumn{2}{|c|}{ Sclerometry } & \multicolumn{2}{c|}{ Ultrasonic Pulse Rate } \\
\cline { 2 - 5 } & IEs & Concrete quality & Vs (m/s) & Concrete quality \\
\hline I-7 & 27.40 & Poor & 1089 & Poor \\
\hline I-2 & 25.70 & Poor & 784 & Poor \\
\hline I-5 & 20.00 & Poor & 305 & Poor \\
\hline I-4 & 28.26 & Poor & 2117 & Poor \\
\hline T-2 & 30.93 & Average & 3116 & Regular \\
\hline S-2 & 30.66 & Average & 3121 & Regular \\
\hline E-11 & 24.13 & Poor & 539 & Poor \\
\hline T-1 & 20.80 & Poor & 309 & Poor \\
\hline E-4 & 26.73 & Poor & 623 & Poor \\
\hline E-10 & 26.26 & Poor & 845 & Poor \\
\hline E-2 & 25.60 & Poor & 737 & Poor \\
\hline I-7 & 28.40 & Poor & 921 & Poor \\
\hline I-5 & 23.86 & Poor & 306 & Poor \\
\hline P-4 & 32.80 & Average & 3070 & Regular \\
\hline P-7 & 33.60 & Average & 3233 & Regular \\
\hline E-6 & 29.00 & Poor & 2130 & Poor \\
\hline T-3 & 27.00 & Poor & 2130 & Poor \\
\hline S-2 & 22.00 & Poor & 2000 & Poor \\
\hline E-5 & 28.00 & Poor & 2200 & Poor \\
\hline E-9 & 28.00 & Poor & 2100 & Poor \\
\hline
\end{tabular}

Table 8. Percentage of humidity in damaged elements.

\begin{tabular}{|l|c|c|c|c|}
\hline \multirow{2}{*}{ Elements } & \multicolumn{3}{c|}{ \% humidity at a height of: } & Incidence on \\
\cline { 2 - 4 } & $\mathbf{0 . 5 0} \mathbf{~}$ & $\mathbf{1 . 3 5} \mathbf{~}$ & $\mathbf{2 . 2 0} \mathbf{~}$ & Maxrosion \\
\hline S-2 & 32.4 & 44.6 & 52.4 & Maximum \\
\hline I-2 & 39.4 & 52.1 & 54.7 & Maximum \\
\hline I-4 & 37.5 & 39.2 & 47.9 & Maximum \\
\hline T-2 & 50.1 & 51.5 & 52.4 & Maximum \\
\hline T-1 & 32.4 & 39.9 & 53.4 & Maximum \\
\hline I-7 & 37.6 & 41.9 & 50.5 & Maximum \\
\hline E-11 & 33.4 & 34.2 & 45.0 & Maximum \\
\hline \multicolumn{4}{|c|}{ \% humidity } \\
\hline P-7 & \multicolumn{3}{|c|}{55.2} & Maximum \\
\hline P-15 & 57.8 & Maximum \\
\hline P-7 & 33.2 & Minimum \\
\hline
\end{tabular}


Table 9. Corrosion potential in damaged elements.

\begin{tabular}{|l|c|l|}
\hline Elements & Results intervals $(\mathbf{m V})$ & \multicolumn{1}{c|}{ Observations } \\
\hline E-4 & $(-341 \mathrm{y}-184)$ & Carbonated wet concrete \\
\hline I-7 & $(-324 \mathrm{y}-160)$ & Carbonated wet concrete \\
\hline E-11 & $(-362 \mathrm{y}-197)$ & Carbonated wet concrete \\
\hline P-4 & $(-380 \mathrm{y}-185)$ & Carbonated wet concrete \\
\hline S-2 & $(-325 \mathrm{y}-169)$ & Carbonated wet concrete \\
\hline T-1 & $(-379 \mathrm{y}-19)$ & Carbonated wet concrete \\
\hline E-5 & $(-154 \mathrm{y} 46)$ & Wet concrete without chloride \\
\hline I-4 & $(-301 \mathrm{y}-167)$ & Carbonated wet concrete \\
\hline P-7 & $(-167 \mathrm{y} 90)$ & Wet concrete without chloride \\
\hline
\end{tabular}

\section{Discussion}

The results of the destructive and non-destructive tests are analyzed below, and the compressive strength of the precast concrete used in the precast Soviet Grand Panel system is obtained, both under the conditions of the original project and under current operating conditions.

\section{A. Destructive testing on elements of the Precast Plant}

From the calculation of the average compressive strength of each series of test piece $f^{\prime} c s$, the mean compressive strength of the batch $\left(f^{\prime} \mathrm{cm}=17.03 \mathrm{MPa}\right)$ and the standard deviation of the batch $(S\llcorner=4.05 \mathrm{MPa})$ were obtained. These are evaluated as acceptable in terms of the uniformity of the concrete batch for the plant control according to the standard [13]. Since there is a doubtful value of $7.66 \mathrm{MPa}$ corresponding to the series taken from element E-12, the statistical value $t_{n}$ is determined, which is compared with $h=1.94$ (for a significance level of $5 \%$ ). Since $t_{n}=2.31>h$, the series is debugged and the mean compressive strength and batch standard deviation are recalculated. The results are $f^{\prime} \mathrm{cm}=18.59 \mathrm{MPa}$ and $\mathrm{S}_{\mathrm{L}}=1.43$ $\mathrm{MPa}$, which are evaluated as excellent. Considering the Student T percentile with a $t$ value $=1,104$, the characteristic resistance is $f^{\prime} c k=17.01 \mathrm{MPa}$. Therefore, it is a medium strength concrete.

This result is confirmed through documentary analysis and interviews. In documents and plans consulted in the file of Project Company No. 15, on February 1, 2019, it is specified that the precast concrete of the Soviet Great Panel System has a characteristic compressive strength value $\mathrm{f}^{\prime} \mathrm{ck}=20 \mathrm{MPa}$ for a $10 \times 10 \mathrm{~cm}$ cube. The equivalent strength for a cylindrical specimen is $16 \mathrm{MPa}$. These values were also 
provided by two founding civil engineers of the Great Soviet Panel Precast Plant in Santiago de Cuba [14].

The compressive strength of the precast concrete of the GPS system obtained is adjusted to the manufacturing requirements of the stages of emergence of the precast system (1940s) and implementation in Cuba (1964-1991). In turn, these results are in correspondence with the international trend of those periods. The report [3] shows that in the period of 1920-1949, concrete strengths were achieved in walls of $14.07 \mathrm{MPa}$ and, between $1950-1969$, of $17.5 \mathrm{MPa}$.

\section{B. Sclerometry and Ultrasonic Pulse Speed Tests on Elements of the Precast Plant}

It is appreciated that in the 7 types of elements there are coincidences with the qualitative evaluation of both trials. The quality of the concrete is medium to regular in 6 types of elements, and in the series concrete taken from element E-12, poor quality was obtained. But, since this series was rejected in the determination of the compressive strength, it will not be considered in the determination of the characteristic IE ( $\left.\mathrm{IE}_{\mathrm{k}}\right)$ either. In other words, the value of 20.00 is rejected because $t_{n}=2.30>h=1.94$ (for a significance level of $5 \%$ ). When the values are recalculated, we have: $I E_{m}=34.16$ and $S L=1.95$, so: $I E_{k}=32$.

The correlation analysis of the results of the destructive test and sclerometry was performed. Figure 2 shows the regression line and the correlation equation (1) obtained.

$$
y=0.6645 x-4.1038(1)
$$

Where "y" is f'ck in MPa and " $\mathrm{x}$ " is IE. The trend, since the correlation coefficient is positive ( $R=0.9025)$, is to increase the compressive strength of the concrete when the IE increases. Since the coefficient of determination (defined as the square of the linear correlation coefficient) $R^{2}=0.8146$, is in the range between 0 and 1 , the estimated line is representative for the data. It can be concluded that the f'ck can be obtained from the IE results. Therefore, equation (1) allows us to determine the compressive strength of the elements that conform the buildings in operation, where the extraction of cores is not possible. 


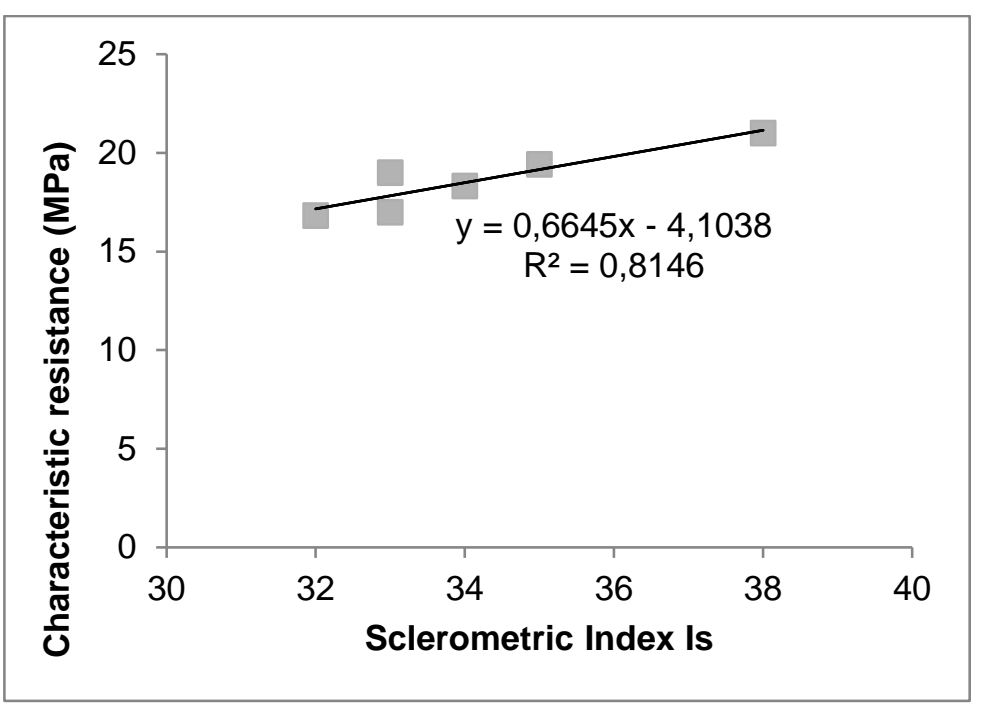

Fig. 2. Regression line for GPS precast concrete.

When IEk is substituted with the elements of the precast plant in equation (1), we obtain $\mathrm{f}^{\prime} \mathrm{ck}=17.16 \mathrm{MPa}, 7.20 \%$ greater than the characteristic value according to the project.

\section{Sclerometry and Ultrasonic Pulse Speed Tests on Elements in Good Conditions that Conform the Buildings}

There are coincidences in the qualitative evaluation of both trials for 10 elements, where an average to regular quality was obtained. A good quality by IE and regular by $\mathrm{V}$ was observed in only in one element.

As it was impossible to carry out destructive tests on the elements that are part of buildings to obtain their compressive strength, it was necessary to correlate the results of the destructive tests, and the sclerometry and ultrasound pulse speed tests of the precast plant, with the results of these same non-destructive tests for elements that conform buildings. For this, the correlation equation (1) is used, with " $x$ " being the IE of the elements tested in the buildings, also, the Sonreb template was used [15]. For the application of the template, coefficients "a", "b", and "c" of the Sonreb curve are determined in the first sheet, introducing the values of the compressive strength according to the destructive test and the $\mathrm{V}$ with the IE of the elements found in the warehouse area of the precast plant. Then, in the second sheet, the $V$ and IE 
of the elements that conform buildings are introduced; thus, the compressive strength of these is obtained.

Table 10 shows the values of the compressive strength obtained by equation (1) and applying the Sonreb template. The results are appreciated as approximate. Then, an average value of these results is determined.

Table 10. Compressive strength of the elements in good condition.

\begin{tabular}{|c|c|c|}
\hline Elements & $f_{c}^{\prime}$ according to equation (1) in MPa & $\mathrm{f}_{\mathrm{c}}^{\prime}$ according to in $\mathrm{MPa}$ \\
\hline I-4 & 18.49 & 17.72 \\
\hline $\mathrm{I}-3$ & 18.49 & 17.72 \\
\hline$E-12$ & 24.46 & 25.77 \\
\hline $1-8$ & 18.49 & 17.72 \\
\hline $1-7$ & 18.49 & 17.72 \\
\hline$E-1$ & 20.48 & 20.43 \\
\hline $\mathrm{I}-7$ & 18.48 & 17.72 \\
\hline $\mathrm{T}-1$ & 15.83 & 14.35 \\
\hline $\mathrm{P}-4$ & 21.81 & 22.83 \\
\hline P-7 & 21.81 & 22.57 \\
\hline $\mathrm{P}-4$ & 21.81 & 22.57 \\
\hline$f_{c m}^{\prime}$ in $\mathrm{MPa}$ & 19.87 & 19.73 \\
\hline $\mathrm{SL}_{\mathrm{L}}$ in $\mathrm{MPa}$ & 2.30 & 3.18 \\
\hline$f_{c k}^{\prime}$ in MPa & 17.46 & 16.4 \\
\hline$f_{c k}^{\prime}$ average en MPa & 16.93 & \\
\hline
\end{tabular}

D. Sclerometry Tests, Ultrasonic Pulse Speed, Determination of the Percentage of Humidity, and the Corrosion Potential in Elements with Pathological Damage that Conform Buildings

High humidity percentages were obtained in 9 elements out of 10, with a maximum incidence on corrosion. In the panel elements, it can be seen that the humidity distribution is not uniform and the highest percentages were found at $2.20 \mathrm{~m}$ high. It can be concluded that the humidity in the panels is descending by infiltration and that the markedly non-linear gradients that exist, due to the non-uniform distribution of humidity, are one of the causes of the fissures that these have. Helene and Pereira [16] argue that the presence of markedly non-linear gradients generate stresses that can exceed the deformation capacity and tensile strength of the material.

In 16 elements out of 20 , there is agreement in the qualitative evaluation of the sclerometry test and the determination of the ultrasonic pulse. The quality of the concrete in these cases is poor for both tests. However, in elements S-2, T-2, P-4 
and P-7, which have high percentages of humidity, the qualitative evaluation of concrete according to the speed of the ultrasonic pulse is regular (with values above $3000 \mathrm{~m} \mathrm{/} \mathrm{s}$ ); according to sclerometry, it is average. These results are in correspondence with the values obtained for the corrosion potential. Since we have elements with high percentages of humidity, according to the result of the measurement of the corrosion potential, a carbonated wet concrete was obtained in these cases. Therefore, the carbonation of the concrete has caused a hardening of the surface and that is why superior qualities are obtained. According to Contreras [17], the only favorable factor of carbonation in concrete is the decrease in porosity when the pores are filled by the $\mathrm{CaCO}_{3}$ deposit, producing an increase in mechanical resistance.

Since carbonation causes a reduction in the $\mathrm{pH}$ of the concrete, it triggers the corrosion of steel. So, despite the positive consequences in relation to concrete, they are not relevant when compared with the negative effects generated by the corrosion of reinforcements.

Analyzing the results of the measurement of the corrosion potential in particular, it can be seen that in 7 elements out of 9 tested, the values of the interval of the corrosion potential are negative, in a range that indicates that in these elements the concrete is wet carbonated. The incidence of the average annual relative humidity in Cuba of $78 \%$ is clear, and the humidity of the elements is between $32.4 \%-57.8 \%$ in these results. Chávez et al. [18] point out the influence of relative humidity on the value of the corrosion potential, reaching more negative values when the relative humidity increases.

Table 11 shows the compressive strength obtained by equation (1) and by the Sonreb template [15]. After the statistical analysis of these results, it is obtained that the compressive strength of the concrete in the damaged elements is: $11.20 \mathrm{MPa}$ and $13.59 \mathrm{MPa}$, respectively, in both ways.

Table 11. Compressive strength in damaged elements.

\begin{tabular}{|l|c|c|}
\hline Elements & $\mathbf{f}^{\prime} \mathbf{c}$ according to equation (1) in MPa & f'c according to Sonreb in MPa \\
\hline $\mathrm{I}-7$ & 14.10 & 17.11 \\
\hline $\mathrm{I}-2$ & 12.97 & 17.08 \\
\hline $\mathrm{I}-3$ & 9.18 & 15.20 \\
\hline
\end{tabular}


Yamila-Concepción Socarrás-Cordoví; Liliana González-Díaz; Eduardo Álvarez-Deulofeu; Mayra GonzálezFernández; Estrella Roca-Fernández; Raúl Torres-Shoembert

\begin{tabular}{|l|c|c|}
\hline Elements & $\mathbf{f}^{\prime} \mathbf{c}$ according to equation (1) in MPa & $\mathbf{f}^{\prime} \mathbf{c}$ according to Sonreb in MPa \\
\hline $\mathrm{I}-4$ & 14.67 & 13.77 \\
\hline $\mathrm{T}-2$ & 16.44 & 14.90 \\
\hline $\mathrm{S}-2$ & 16.26 & 14.73 \\
\hline $\mathrm{E}-11$ & 11.93 & 17.31 \\
\hline $\mathrm{T}-1$ & 9.71 & 16.17 \\
\hline $\mathrm{E}-4$ & 13.65 & 19.62 \\
\hline $\mathrm{E}-10$ & 13.34 & 17.33 \\
\hline $\mathrm{E}-2$ & 12.90 & 17.31 \\
\hline $\mathrm{I}-7$ & 14.76 & 19.18 \\
\hline $\mathrm{I}-6$ & 11.75 & 20.44 \\
\hline $\mathrm{P}-4$ & 17.69 & 16.56 \\
\hline $\mathrm{P}-7$ & 18.22 & 16.96 \\
\hline $\mathrm{E}-6$ & 15.16 & 15.15 \\
\hline $\mathrm{T}-3$ & 13.83 & 13.43 \\
\hline $\mathrm{S}-2$ & 10.51 & 9.71 \\
\hline $\mathrm{E}-5$ & 14.50 & 14.13 \\
\hline $\mathrm{E}-9$ & 14.50 & 14.34 \\
\hline $\mathrm{f}^{\prime}$ cmin $\mathrm{MPa}$ & 13.80 & 16.02 \\
\hline $\mathrm{S}$ in $\mathrm{MPa}$ & 2.35 & 2.38 \\
\hline $\mathrm{f}^{\prime}$ ck in $\mathrm{MPa}$ & 11.20 & 13.59 \\
\hline & & \\
\hline
\end{tabular}

On the other hand, Lewicki [19] considers that the humidity in the concrete reduces its resistance to compression by 10 to $15 \%$, when the humidity in the element goes from 5 to $20 \%$. Since all the elements to which the humidity percentage was measured exceed these values, this reduction, applied at $16 \mathrm{MPa}$ and $13.6 \mathrm{MPa}$, is obtained. It is observed that the results are approximate and an average value of these is determined, being $f^{\prime} c k=12.79 \mathrm{MPa}$.

\section{Conclusions}

From the results of the destructive and non-destructive tests carried out in the framework of this research, it is specified that: i) The compressive strength of the concrete of the precast GPS system according to the project is $16.00 \mathrm{MPa}$, and ii) It can be assumed that the resistance to compression of concrete in precast elements in good technical-constructive conditions, which conform buildings in operation, is 16.93 $\mathrm{MPa}$, as well as $12.79 \mathrm{MPa}$ in elements with pathological damage.

That is, in the precast elements in good technical-constructive condition, which conform the buildings in operation, the compressive strength is $5.80 \%$ higher than that required by the project, remaining within the range of medium strength. However, in the elements with the presence of pathological damage it decreases by 
$25.78 \%$, classifying it as low resistance. In these elements, chemical deterioration processes are evident, caused by the water exposure, which generates the formation of soluble paste compounds, loss of mass, mechanical resistance, among other alterations. The carbonation of the concrete is also triggered, which in turn causes the corrosion of the reinforcing steel. This corrosion leads to the cracking of concrete, delamination of steel, decrease of the concrete-steel adhesion and other manifestations, which affect the durability of the concrete. Therefore, the impact of the durability of concrete on the seismic resistance of buildings built with this precast system must be evaluated.

\section{AUTHOR's CONTRIBUTION}

Socarrás-Cordoví report writing, information research and testing; González-Díaz review of the report and information research; Álvarez-Deulofeu review of the report and information research; González-Fernández carrying out of the tests; RocaFernández: Carrying out of the tests; and, Torres-Shoembert carrying out of the tests.

\section{REFERENCES}

[1] A. Díaz, "Deterioro de la imagen de un conjunto habitacional en la periferia de la ciudad", in IV Memorias del Evento Internacional Ciudad, Imagen y Memoria, Santiago de Cuba, Cuba, 2005, pp.14-29.

[2] G. Morejón-Blanco, Y. Berenguer-Heredia, K. Leyva-Chang, D. Candebat-Sánchez, and A. ArtímezNumas, "Comportamiento estructural del sistema prefabricado Gran Panel Soviético a partir de las modificaciones realizadas por los habitantes ante sismos de gran magnitud," Ciencias de la Tierra y el Espacio, vol. (15), pp. 85-96, Jun. 2014.

[3] Federal Emergency Management Agency, FEMA 273-NEHRP Guidelines for the Seismic Rehabilitation of Buildings, 1997.

[4] American Society of Civil Engineers, ASCE/SEI 7-05-Seismic Evaluation and Retrofit of Existing Buildings, 2013.

[5] Gaceta Oficial del Distrito Federal, Normas para la Rehabilitación Sísmica de edificios de concreto dañados por el Sismo del 19 de septiembre, 2017. http://www.smie.org.mx/archivos/informaciontecnica/reglamentos-construccion-mexico/ciudad-de-mexico/ciudad-de-mexico-normas-rehabilitacionsismica-edificios-danados-2017.pdf

[6] Normalización O. N. D., NC 318-Ensayos al Hormigón-Muestreo, preparación y ensayos de testigos al hormigón, 2015.

[7] Normalización O. N. D., NC-724-Ensayos del Hormigón. Resistencia del Hormigón en Estado Endurecido, 2015. 
Yamila-Concepción Socarrás-Cordoví; Liliana González-Díaz; Eduardo Álvarez-Deulofeu; Mayra GonzálezFernández; Estrella Roca-Fernández; Raúl Torres-Shoembert

[8] R. Solís, "Predicción de la resistencia del concreto con base en la velocidad de pulso ultrasónico y un índice de calidad de los agregados," Ingeniería, vol. 8, pp.41-52, May. 2004.

[9] Normalización O. N. D., NC 246-Determinación de la resistencia a la compresión con el uso de Esclerómetros Tipos $N$ y NR, 2003.

[10] Normalización O. N. D., NC/ISO 1920-7-Ensayos no Destructivos al Hormigón Endurecido, 2015.

[11] P. Tejera, and O. Álvarez, Conservación de Edificaciones, La Habana, Cuba: Félix Varela, 2013.

[12] Proceq, Manual de operación 82039201S Datasheet, 2017. https://www.proceq.com/uploads/tx proceqproductcms/import data/files/Profometer Operating\%20Instru ctions Spanish high.pdf

[13] Normalización O. N. D., NC 192-Hormigón hidráulico-Cálculo de la resistencia característica real a la compresión, 2007.

[14] Y. Socarrás-Cordoví, L. Rodríguez and R. Balart Casas Interview, Cuba, Dec. 2018.

[15] Proceq, Using Excel to determine Sonreb curve coefficients, 2018. https://www.yumpu.com/en/document/read/14104870/1-using-excel-to-determine-sonreb-curvecoefficients-proceq

[16] P. Helene, and F. Pereira, Rehabilitación y mantenimiento de estructuras de concreto, Sao Paulo: Brasil, 2007.

[17] F. Contreras, "Validación de escorias de horno de arco eléctrico mediante su uso como adición en hormigón," Doctoral Thesis, Universidad de Málaga, Spain, 2017.

[18] E. Chávez, T. Pérez, J. Reyes, and F. Corvo, "Deterioration of concrete structures due to carbonation in tropical marine environment and accelerated carbonation chamber," Revista Técnica de la Facultad de Ingeniería Universidad del Zulia, vol. 36 (2), pp. 104-113, Agu. 2013.

[19] B. Lewicki, Edificios de viviendas prefabricadas con elementos de grandes paneles, Polonia: Arkady, 1968. 